Volume 15 Nomor 2, Desember 2019

\title{
Pengaruh Partisipasi Pelatihan, Responsibility dan Motivasi Kerja terhadap Kinerja Kepala Desa di Kabupaten Gorontalo
}

\author{
Roni Mohamad \\ IAIN Sultan Amai Gorontalo \\ ronimohamad@iaingorontalo.ac.id
}

\begin{abstract}
The aims of this research to determines the effect of participation in training, work responsibility, work motivation towards the performanceon a head of village at Gorontalo Regency. These research was conducted at Gorontalo local government that involved sample 137 head of Village. To determine sample selected by proportionate random sampling technique. Collecting data by using Likert scale consists of five option. Meanwhile the data analyzed with path analysis. The results are: (1) Participation in Training directly positive affects performance, (2) Work Responsibility directly positive affects performance, (3) Work motivation had a direct positive impact on performance, (4) Participation in training directly positive influence work motivation, (5) Work Responsibility directly positive influence work motivation. Based on this research, Participation in training, work responsibility, work motivation has direct positive effect on a head of village performance. Futhermore it should be developed by Regency goverment, and central governance to make be better of performance head of village.
\end{abstract}

Keyword: participation training, responsibility, work motivation and performance

\section{A. PENDAHULUAN}

Undang-Undang Nomor 32 Tahun 2004 tentang Pemerintahan Daerah menyebutkan bahwa pengertian desa sebagai kesatuan masyarakat hukum yang memiliki batas wilayah, yang berwenang untuk mengatur dan mengurus kepentingan masyarakat setempat, berdasarkan asalusul dan adat istiadat setempat yang diakui dan dihormati dalam sistem pemerintahan Negara Kesatuan Republik Indonesia.

Konsep di atas menunjukkan bahwa desa memiliki indikator-indikator berupa (1) kesatuan masyarakat, (2) memiliki wilayah, (3) kewenangan mengatur dan mengurus kepentingan masyarakat dalam arti memiliki pemerintahan tersendiri, (4) memiliki adat istiadat, dan (5) memiliki pengakuan dari pemerintah. 
Diantara kelima indikator tersebut, yang menarik untuk diangkat kepermukaan adalah indikator memiliki pemerintahan tersendiri. Pemerintahan desa merupakan bagian vital yang menjalankan fungsi-fungsi pelayanan di front terdepan. Konotasi populer tentang pemerintahan desa adalah pemerintahan terkecil yang memiliki pengaruh besar. Konotasi ini muncul akibat rincian tugas pemerintahan desa yang mencakup antara lain adalah; (1) meningkatkan kesejahteraan masyarakat; (2) memelihara ketentraman dan ketertiban masyarakat; (3) melaksanakan kehidupan demokrasi; (4) melaksanakan prinsip tata pemerintahan desa yang bersih dan bebas dari Kolusi, Korupsi dan Nepotisme; (5) menjalin hubungan kerja dengan seluruh mitra kerja pemerintahan desa; (6) menaati dan menegakkan seluruh peraturan perundang-undangan; (7) menyelenggarakan administrasi pemerintahan desa yang baik; (8) melaksanakan dan mempertanggungjawabkan pengelolaan keuangan desa; (9) melaksanakan urusan yang menjadi kewenangan desa; (10) mendamaikan perselisihan masyarakat di desa; (11) mengembangkan pendapatan masyarakat dan desa; (12) membina, mengayomi dan melestarikan nilai-nilai sosial budaya dan adat istiadat; (13) memberdayakan masyarakat dan kelembagaan di desa; dan (14) mengembangkan potensi sumber daya alam dan melestarikan lingkungan hidup.

Rincian tugas tersebut menjadi kontrak kerja Kepala Desa yang direkruit melalui mekanisme pemilihan Kepala Desa oleh rakyat. Sebagai imbalannya, Kepala Desa akan mendapatkan Gaji dan Tunjangan beserta penghasilan lain yang sah.

Di Kabupaten Gorontalo, Kepala Desa mendapatkan gaji dan tunjangan dari pemerintah Daerah, mendapatkan tunjangan dari Pemerintah Propinsi, dan mendapatkan maslahat lainya dari warga masyarakat yang sifatnya insidentil seperti sedekah pada perayaan pesta dan perayaanperayaan lainnya.

Dalam hal menjalankan pemerintahan, Kepala Desa dan seluruh staf mendapatkan alokasi anggaran untuk pembiayaan pembangunaan dan pemerintahan. Kewenangan kepala desa dapat dijalankan dengan menggunakan dana yang di alokasikan Pemerintah Kabupaten Gorontalo di sebut sebagai Alokasi Dana Desa (ADD). Ini menunjukan bahwa tidak ada alasan yang membenarkan Kepala Desa tidak dapat menyelenggarakan layanan publik yang dibutuhkan masyarakat di tingkat Desa.

Kepala Desa sebagai Kepala Pemerintahan di Tingkat Desa setidaknya memiliki beberapa hak yakni; (1) kewenangan, (2) pembiayaan dalam rangka menyelenggarakan kewenangan, (3) kesejahteraan yang layak, (4) dukungan masyarakat, (5) aturan hukum yang memayungi. Dengan 
lima hak yang dimiliki oleh Kepala Desa tersebut maka diharapkan kesejahteraan masyarakat akan meningkat.

Realitas di lapangan menunjukkan bahwa kesejahteraan masyarakat desa tidak tercapai. Banyaknya penduduk miskin, adalah indikator bahwa masyarakat desa belum tersejahterakan oleh pemerintah desa. Bedasarkan data Badan Pusat Statistik Kabupaten Gorontalo tahun 2013 bahwa penduduk miskin dominan berada di wilayah pedesaan. Kondisi ini berlaku pada semua kelompok kemiskinan yang dibagi dalam tiga kelompok utama.

Realitas lain yang ditunjukkan minimnya kesejahteraan adalah kemampuan masyarakat melunasi pajak bumi dan bangunan, jumlah masyarakat yang dapat berobat ke Dokter selagi sakit, dan jumlah masyarakat yang dapat melanjutkan anaknya masuk sekolah yang lebih tinggi. Realitas inipula yang menunjukan bahwa posisi Kepala Desa sebagai pimpinan pemerintahan tidak berjalan sesuai harapan masyarakat. Praksisnya, ada masalah besar dalam kinerja Kepala Desa sebagai leader pemerintahan terdepan dan bersentuhan langsung dengan masyarakat.

Kinerja menurut Caine (2001:12) sebagaimana diketahui adalah serangkaian tindakan kompleks yang dilaksanakan mengintegrasikan keterampilan dan pengetahuan untuk mendapatkan hasil yang bernilai. Mathis \& Jackson (2009:8) merinci tiga faktor situasional mempengaruhi kinerja yaitu : (1) kemampuan individual untuk melakukan pekerjaan tersebut, (2) tingkat usaha yang dicurahkan, dan (3) dukungan organisasi. Colquitt (2009:28) menyatakan faktor-faktor yang mempengaruhi kinerja antara lain; (1) Kepuasan kerja, (2) Stress, (3) Motivasi, (4) Kepercayaan, keadilan dan Etika, (5) Pembelajaran dan Pengambilan Keputusan. Sedangkan faktor-faktor yang mempengaruhi kelima aspek itu adalah: (1) Budaya Organisasi, (2) Struktur Organisasi, (3) Kepemimpinan yang mencakup gaya dan perilaku, (4) Kepemimpinan yang mencakup kekuasaan dan pengaruh, (5) Tim dalam hal ini proses, (6) Karakteristik tim, (7) Kepribadian dan Nilai-nilai budaya, dan (8) kemampuan. Tomporowski dan Mozrall Drury (2008:262) mengatakan bahwa Tanggung Jawab kerja (Responsibility) mempengaruhi kinerja. 


\section{Konstalasi Penelitian}

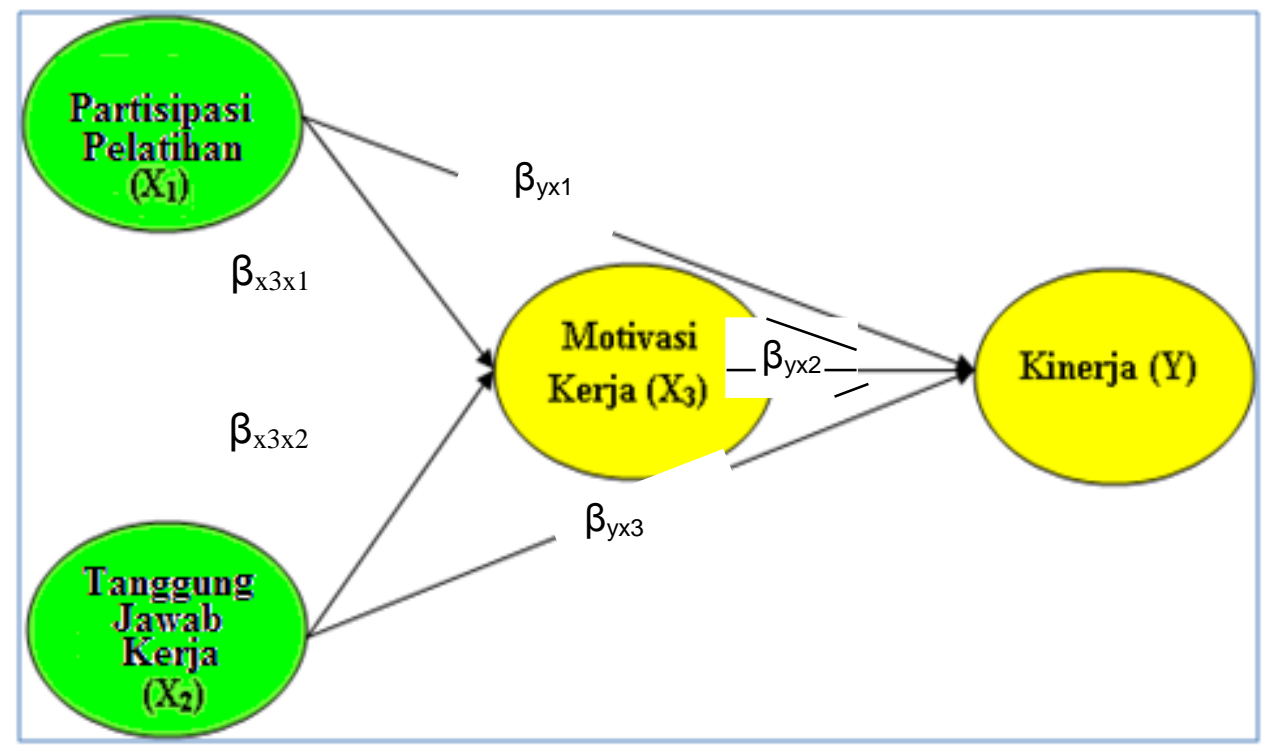

\section{B. KAJIAN TEORETIK}

\section{Deskripsi Konseptual Kinerja Kepala Desa}

\section{Kinerja}

Schermerhorn (2010 : 14) menyatakan bahwa kinerja adalah kuantitas dan kualitas kerja yang dihasilkan. Gibson, Ivancevvick, Donelly (2006: 372) mengemukakan bahwa kinerja merupakan tingkat keberhasilan dalam melaksanakan tugas serta kemampuan untuk mencapai tujuan yang telah ditetapkan, kinerja dinyatakan baik dan sukses jika tujuan yang diinginkan dapat tercapai dengan baik, terutama pada kualitas dan efisiensi dari kriteria keefektifpan.

Arnold (2006:24) mengatakan bahwa kinerja diartikan sebagai kesesuaian antara kegiatan individual dengan tujuan organisasi, kinerja yang efektif akan meningkatkan kerja yang optimal. Kinerja juga memperlihatkan seberapa jauh seseorang dapat mewujukan tujuan-tujuannya. Kinerja menurut Colquitt, Lepine, dan Wesson (2009: 37) merupakan tolok ukur keberhasilan dalam melakukan suatu pekerjaan. Dihubungkan dengan dengan peran individu dalam organisasi, kinerja adalah serangkaian perilaku atau kegiatan individu yang sesuai dengan harapan atau keinginan organisasi tempat bekerja.

Robin (2006: 340) menyatakan bahwa kinerja pada dasarnya adalah apa yang dilakukan atau tidak dilakukan oleh seseorang dalam organisasi dan oleh sebab itu dapat mempengaruhi 
seberapa besar kontribusi mereka kepada organisasi, yang meliputi kuantitas output, kualitas output, jangka waktu output dan kehadiran di tempat kerja.

Armstrong dan Baron (2001: 16-17) mengatakan bahwa ada beberapa faktor yang mempengaruhi kinerja antar lain: (1) Faktor personal, meliputi berbagai keterampilan individu, kompetensi, kecerdasan, kemandirian, kreativitas, motivasi, keyakinan; (2) Faktor kepeminpinan yang berkualitas dan pemberian motivasi, bimbingan dan dorongan; (3) Faktor tujuan, faktor sistem, pekerjaan dan fasilitas yang diberikan oleh organisasi; (4) Faktor situasional meliputi perubahan dan penekanan dari faktor internal dan eksternal (perubahan).

Kepala Desa sesuai Peraturan Pemerintah No. 72 Tahun 2005 merupakan pimpinan penyelenggaraan pemerintahan desa berdasarkan kebijakan yang ditetapkan bersama Badan Permusyawaratan Desa (BPD). Masa jabatan Kepala Desa adalah 6 tahun, dan dapat diperpanjang lagi untuk satu kali masa jabatan. Kepala Desa juga memiliki wewenang menetapkan Peraturan Desa yang telah mendapat persetujuan bersama BPD. Sedangkan Tugas dan Wewenang Kepala desa telah di atur dalam Pasal 15 Undang-Undang yang sama.

Henry Fayol (dalam Robins \& Coulter, 2007 : 62) mengatakan ada lima fungsi manajemen yang harus diemban oleh pemimpin: (1) perencanaan, (2) pengorganisasian, (3) pelaksanaan, (4) pengkoordinasian, dan (5) pengontrolan. Kepala Desa, karena merupakan pimpinan pemerintahan di Desa, maka harus melaksanakan fungsi-fungsi manajemen tersebut.

Berdasarkan konsep-konsep yang telah dikemukakan di atas, maka dapat dirumuskan sintesis Kinerja adalah hasil pekerjaan yang dilakukan oleh seseorang baik secara individual maupun secara kelembagaan untuk melaksanakan tugas sesuai fungsi manajemen untuk pencapaian tujuan..

\section{Partisipasi Pelatihan}

Haris dan Hardtman (2002:111) mengatakan bahwa teori partisipasi lebih fokus membahas tentang proses keterlibatan individu dalam kegiatan. Locke (2003: 213)mengatakan bahwa partisipasi pada hakekatnya memiliki makna mengikutsertakan, ikut mengambil bagian.

Locke mengatakan bahwa partisipasi pada hakekatnya memiliki makna mengikutsertakan, ikut mengambil bagian saerta partisipasi dapat juga berarti pembuat keputusan menyarankan kelompok atau masyarakat ikut terlibat dalam bentuk penyampaian saran dan pendapat, barang, keterampilan, bahan dan jasa ( 2003 : 213). Partisipasi bermakna bahwa kelompok mengenal 
masalah mereka sendiri, mengkaji pilihan mereka, membuat keputusan, dan memecahkan masalahnya

Edwin B. Flippo (2010:285) mengatakan bahwa pelatihan adalah tindakan meningkatkan pengetahuan dan keterampilan pekerja untuk melakukan pekerjaan tertentu. Pelatihan melibatkan bagian keterampilan yang dibutuhkan untuk melaksanakan pekerjaan-pekerjaan spesifik. Tujuanya untuk mencapai perubahan dalam perilaku dari keikutsertaanya dalam pelatihan dan membangun kemampuan mereka melakukan pekerjaan-pekerjaan dengan baik. Pada intinya pelatihan harus dapat melakukan perubahan positif dalam hal (1) pengetahuan, (2) keterampilan dan (3) sikap pekerja.

Pelatihan didefinisikan oleh Ivancevich (2008 : 212) sebagai usaha untuk meningkatkan kinerja pegawai dalam pekerjaannya sekarang atau dalam pekerjaan lain yang akan dijabatnya segera. Ivancevich mengemukakan pelatihan (training) adalah sebuah proses sistematis untuk mengubah perilaku kerja seorang/sekelompok pegawai dalam usaha meningkatkan kinerja organisasi. Pelatihan terkait dengan keterampilan dan kemampuan yang diperlukan untuk pekerjaan yang sekarang dilakukan. Pelatihan berorientasi ke masa sekarang dan membantu untuk menguasai keterampilan dan kemampuan (kompetensi) yang spesifik agar berhasil dalam mengerjakan tugas.

Pelatihan menurut Ulrich (2007:317) adalah sebuah proses dimana orang meningkatkan kemampuanya untuk membantu dalam hal pencapaian tujuan organisasi.

Berdasarkan konsep-konsep yang dikemukakan di atas, maka dapat disintesiskan bahwa yang dimaksud dengan Partisipasi Pelatihan adalah upaya seseorang untuk meningkatkan kemampuan yang mencakup perencanaan, pengorganisasian, pelaksanaan, monitoring dan evaluasi. Yang ditunjukkan dalam indikator: (1) keikutsertaan dalam pendidikan dan latihan, (2) menerapkan hasil-hasil pelatihan dalam pelaksanaan tugas, (3) keberhasilan dalam melaksanakan tugas.

\section{Responsibility}

Crrawford (2004:77) Responsibility adalah fenomena psikologis di mana orang cenderung untuk mengambil tindakan atau merasa tanggung jawab di hadapan sekelompok besar orang.

Ivancevic (2006 : 278) menyatakan bahwa tanggung jawab kerja adalah jumlah pekerjaan yang orang harus lakukan. Sementara menurut Lynch \& Cruise (2006 : 788) Ukuran tanggung jawab 
berada pada pekerjaan yang dilakukan, ukuran sasaran yang diselesaikan. Wickens (2012:194) mendefinisikan tanggung jawab sebagai hubungan antara penawaran dan permintaan sumber daya tugas.

Tanggung jawab kerja berkenaan dengan kuantitas pekerjaan dan kualitas aktivitas yang dilaksanakan. Kata Ivancevich (2002:643) tanggung jawab kerja yang berlebihan bisa menyebabkan seseorang bekerja pada jangka waktu yang lama yang bisa menyebabkan kelelahan dan kerjadian-kejadian lainya.

Parasuraman dan Hancock (2001 : 11) menggambarkan tanggung jawab kerja sebagai fungsi yang sangat dinamis dan berkembang terus dari kombinasi tuntutan tugas, strategi operator, dan lingkungan kerja. Seiring dengan peningkatan tanggung jawab tugas, operator dapat menerapkan strategi kontrol adaptif untuk mengimbangi konsekuensi kinerja dan untuk mempertahankan tanggung jawab kerja dalam kisaran yang dikelola. Operator dapat mengubah kriteria kinerja, diimbangi tugas personil lainnya, atau terlibat sistem otomatisasi untuk mengalokasikan perhatian pada komponen tugas-tugas kritis.

Tanggung jawab kerja dipengaruhi oleh 2 faktor, yaitu faktor eksternal dan faktor internal (Ivancevich 2002:645). Faktor eksternal, yaitu tanggung jawab yang berasal dari luar tubuh, seperti; (1) tugas-tugas yang bersifat fisik, seperti tempat kerja, tata ruang, alat dan sarana kerja, kondisi kerja, sikap kerja, dan tugas-tugas yang bersifat psikologis, seperti kompleksitas pekerjaan, tingkat kesulitan, tanggung jawab pekerjaan; (2) organisasi kerja, seperti lamanya waktu bekerja, waktu istirahat, shift kerja, kerja malam, sistem penggajian, model struktur organisasi, pelimpahan tugas dan wewenang; dan (3) lingkungan kerja adalah lingkungan kerja fisik, lingkungan kimiawi, lingkungan kerja biologis dan lingkungan kerja psikologis.

Faktor internal adalah faktor yang berasal dari dalam tubuh itu sendiri akibat dari reaksi tanggung jawab kerja eksternal. Faktor internal meliputi faktor somatis (jenis kelamin, umur, ukuran tubuh, status gizi, dan kondisi kesehatan) dan faktor psikis (motivasi, persepsi, kepercayaan, keinginan dan kepuasan).

Berdasarkan teori yang telah dikemukakan di atas, maka dapat disintesiskan bahwa yang dimaksud dengan tanggung jawab kerja adalah sejumlah pekerjaan yang harus diselesaikan seseorang dalam jangka waktu tertentu, yang melibatkan kemampuan fisik maupun mental dengan indikatornya adalah tanggung jawab eksternal dan internal serta kerja-kerja fisik dan kerja mental. 


\section{Motivasi Kerja}

Motif adalah alasan untuk melakukan sesuatu. Motivasi berkenaan dengan faktor-faktor yang mempengaruhi orang untuk melakukan dengan cara-cara tertentu. Motivasi kata Amstrong (2006 : 252) dapat digambarkan sebagai perilaku mencapai tujuan. Kreitner dan Kinicki (2003: 234) mengatakan bahwa teori motivasi kontemporer berakar dari bagian dalam prinsip hedonisme, yang menyatakan bahwa orang mencari kesenangan dan menghindari rasa sakit. Senada dengan Kreitner, Moorhead dan Griffin, Condrey (2005 : 475) mengatakan bahwa dorongan untuk memenuhi kebutuhan penting adalah denominator umum di antara berbagai teori motivasi. Meskipun kedua klaim ini tidak saling eksklusif, perlu dicatat bahwa terlalu banyak penekanan pada hedonisme sebagai kunci motivasi menyiratkan pandangan sangat sempit perilaku manusia dan kompleksitas hubungan dengan sesama pekerja.

Mullins (2006 : 184) berpendapat motivasi dapat digambarkan sebagai arah dan keteguhan tindakan. Hal ini berkaitan dengan mengapa orang memilih tindakan tertentu dalam preferensi untuk orang lain, dan mengapa mereka terus dengan tindakan dipilih, meskipun berlangsung lama, atau saat menghadapi kesulitan dan masalah. Motivasi adalah keinginan dalam diri seseorang yang menyebabkan orang untuk bertindak. Orang biasanya bertindak karena satu alasan untuk mencapai tujuan. Dengan demikian, motivasi berorientasi pada pencapaian tujuan yang telah diarahkan, dan jarang terjadi dalam kekosongan. Kata-kata dibutuhkan, diinginkan, keinginan, dan dorongan semua mirip dengan motif, sebagai kata asal dari motivasi.

Mullins (2003:185) mengatakan ada dua bentuk motivasi yakni intrinsik dan ekstrinsik. Motivasi ekstrinsik berkaitan dengan imbalan nyata seperti gaji dan tunjangan, keamanan, promosi, kontrak kerja, lingkungan kerja dan kondisi kerja. Imbalan nyata ditentukan pada tingkat organisasi dan mungkin sebagian besar di luar kendali manajer. Motivasi intrinsik berkaitan dengan penghargaan psikologis seperti kesempatan untuk menggunakan kemampuan seseorang, rasa tertantang dan prestasi, apresiasi menerima, pengakuan positif, dan diperlakukan dengan cara peduli dan perhatian. Pemberian penghargaan psikologis biasanya dapat ditentukan oleh tindakan dan perilaku manajer sendiri.

Berdasarkan konsep-konsep yang telah dikemukakan di atas, maka dapat disintesiskan bahwa yang dimaksud dengan Motivasi Kerja adalah dorongan yang berasal dari dalam diri untuk melaksanakan pekerjaan dan tanggungjawab demi memenuhi kebutuhan yang diharapkan. 


\section{Tujuan Penelitian}

Penelitian ini bertujuan untuk menguji: (1) Pengaruh langsung positif Partisipasi Pelatihan terhadap Kinerja Kepala Desa. (2) Pengaruh langsung positif Responsibility terhadap Kinerja Kepala Desa. (3) Pengaruh langsung positif Motivasi Kerja terhadap Kinerja Kepala Desa. (4) Pengaruh langsung positif Partisipasi Pelatihan terhadap Motivasi Kerja Kepala Desa. (5) Pengaruh langsung positif Responsibility terhadap Motivasi Kerja Kepala Desa

\section{Metodologi Penelitian}

Penelitian ini akan dilaksanakan di lingkungan Pemerintah Kabupaten Gorontalo khususnya Kepala-Kepala Desa yang tersebar di 18 Kecamatan. Waktu Penelitian akan dilaksanakan selama 12 Bulan terhitung mulai bulan Januari hingga Desember 2013. Metode penelitian yang digunakan adalah metode survey dan analisis jalur.

Populasi penelitian ini adalah Kepala Desa di Wilayah Kabupaten Gorontalo yang berjumlah sebanyak 210 orang. Pengambilan sample dilakukan dengan menggunakan teknik Probability sampling. Formula digunakan adalah formula Slovin yang menghasilkan jumlah responden sebanyak 137 orang

Instrument penelitian terdiri dari 4 (empat) yakni instrumen; Kinerja Kepala Desa, Motivasi Kerja, Responsibility, Partisipasi Pelatihan. Sebelum digunakan sebagai alat penjaring data, instrumen tersebut terlebih dahulu diuji kualitasnya. Kualitas instrumen ditentukan oleh validitas (kehandalan) dan reliabilitas (keterpercayaan). Oleh sebab itu setelah penyusunan instrumen dilanjutkan dengan uji coba instrumen yang melibatkan sampel 30 responden.

Hasil uji validitas instrumen Kinerja Kepala Desa semula berjumlah 75 butir, ditemukan 7 (dua) butir yang tidak memenuhi kriteria validitas sedangkan 68 butir lainnya dinyatakan valid. Butir instrumen yang tidak valid tersebut didrop. Kemudian disusun kuisioner sebanyak 68 butir. Perhitungan reliabilitas menunjukkan $r=0.979$. Dengan demikian instrumen Kinerja Kepala Desa yang dijadikan alat ukur dalam penelitian ini memenuhi tingkat kehandalan yang sangat tinggi.

Hasil uji validitas instrumen Partisipasi Pelatihan semula berjumlah 44 butir, ditemukan 3 (tiga) butir yang tidak valid, sedangkan 41 butir lainnya dinyatakan valid. Butir instrument tidak valid didrop. Kemudian disusun kuisioner sebanyak 41 butir. Perhitungan reliabilitas menunjukkan $\mathrm{r}=$ 0.978. Dengan demikian instrumen Partisipasi Pelatihan yang dijadikan alat ukur dalam penelitian ini memenuhi tingkat kehandalan yang sangat tinggi. 
Hasil perhitungan validitas instrumen Responsibility semula 40 butir, ditemukan 4 (empat) butir tidak valid. Butir instrumen tidak valid tersebut didrop. Kemudian disusun kuisioner sebanyak 36 butir. Perhitungan reliabilitas menunjukkan $\mathrm{r}=0.913$. Dengan demikian instrumen Responsibility yang dijadikan alat ukur dalam penelitian ini memenuhi tingkat kehandalan yang sangat tinggi.

Hasil perhitungan validitas instrumen Motivasi Kerja semula 48 butir, ditemukan 3 (tiga) butir tidak valid sedangkan 45 butir lainnya dinyatakan valid. Butir instrument tidak valid didrop kemudian disusun kuisioner sebanyak 45 butir.

Perhitungan reliabilitas menunjukkan $\mathrm{r}=0.953$. Dengan demikian instrumen Motivasi Kerja yang dijadikan alat ukur dalam penelitian ini memenuhi tingkat kehandalan yang sangat tinggi.

\section{HASIL PENELITIAN DAN PEMBAHASAN}

\section{Deskripsi Data Hasil Penelitian}

Pengumpulan data penelitian telah mencakup data penelitian Pelatihan $\left(\mathrm{X}_{1}\right)$, Responsibility $\left(\mathrm{X}_{2}\right)$, Motivasi Kerja $\left(\mathrm{X}_{3}\right)$, Kinerja Kepala Desa (Y). Berdasarkan hasil penjaringan data melalui instrumen penelitian yang telah melalui uji coba menggambarkan karakteristik sebagaimana di sampaikan pada Tabel 1 di bawah ini.

\section{Tabel 1 Skor Instrumen}

\begin{tabular}{|l|c|c|c|c|c|c|}
\hline \multirow{2}{*}{ Variabel } & \multirow{2}{*}{$\sum$ Butir } & \multirow{2}{*}{ Skala } & \multicolumn{2}{c|}{ Skor Teoretik } & \multicolumn{2}{c|}{ Skor Empiris } \\
\cline { 4 - 8 } & & & Terendah & Tertinggi & Terendah & Tertinggi \\
\hline Kinerja Kepala Desa & 67 & 5 & 67 & 335 & 255 & 327 \\
\hline Partisipasi Pelatihan & 41 & 5 & 41 & 205 & 140 & 187 \\
\hline Responsibility & 36 & 5 & 36 & 180 & 112 & 170 \\
\hline Motivasi Kerja & 45 & 5 & 45 & 225 & 156 & 204 \\
\hline
\end{tabular}

1. Instrumen Kinerja Kepala Desa terdiri dari 67 sehingga secara teoritik rentang skor yang diperoleh dari anggota sample adalah 67- 335. Hasil pengumpulan data menunjukan skor terendah 255 dan tertinggi 327.

2. Partisipasi Pelatihan terdiri dari 41 sehingga secara teoritik rentang skor yang diperoleh dari anggota sampel adalah 41 - 205. Hasil pengumpulan data menunjukan skor terendah 140 dan tertinggi 187. 
3. Instrumen Responsibility terdiri dari 36 sehingga secara teoritik rentang skor yang diperoleh dari anggota sampel adalah 36 - 180. Hasil pengumpulan data menunjukan skor terendah 112 dan tertinggi 170.

4. Instrumen Motivasi Kerja terdiri dari 45 sehingga secara teoritik rentang skor yang diperoleh dari anggota sampel adalah $45-225$. Hasil pengumpulan data menunjukan skor terendah 156 dan tertinggi 204.

Hasil penelitian secara deskritif bahwa variabel Partisipasi Pelatihan $\left(\mathrm{X}_{1}\right)$, Responsibiliy $\left(\mathrm{X}_{2}\right)$, Motivasi Kerja $\left(\mathrm{X}_{3}\right)$, Kinerja Kepala Desa (Y). Variabel Kinerja (Y) diperoleh rata-rata sebesar 290,99; median 291,59; modus 295,59; dan standar deviasi 17,86. Variabel partisipasi Pelatihan (X1) diperoleh rata-rata sebesar 163,78; median 164,22; modus 165,38; dan standar deviasi 11,57. Variabel Responsibiliy diperoleh rata-rata sebesar 139,56; median 137,13; modus 133,50; dan standar deviasi 13,81. Sedangkan untuk variavel Motivasi diperoleh rata-rata sebesar 182,72; median 182,91; modus 182,88; dan standar deviasi 11,79.

\section{Pengujian Persyaratan Analisis}

Uji persyaratan analisis dimaksud adalah uji linieritas regresi, normalitas galat taksiran untuk setiap persamaan regresi.

\section{Uji Linieritas dan Signifikansi Regresi}

Hasil perhitungan menunjukan hal-hal sebagai berikut:

1. Regresi $Y$ atas $X_{1}$ adalah: $\hat{Y}==$ Model regresi $\hat{Y}=130,059+0,982 X_{1}$, hasil perhitungan bersifat linier.

2. Regresi $Y$ atas $X_{2}$ adalah: $\hat{Y}=$ Model regresi $\hat{Y}=194,861+0,690 X_{2} X_{2}$ hasil perhitungan bersifat linier

3. Regresi $\mathrm{Y}$ atas $\mathrm{X}_{3}$ adalah $\hat{\mathrm{Y}}==119,029+0,942 \mathrm{X}_{3}$ hasil perhitungan bersifat linier

4. Regresi $X_{3}$ atas $X_{1}$ adalah $\hat{X}_{3}=104,758+0,476 X_{1}$ hasil perhitungan bersifat linier

5. Regresi $X_{3}$ atas $X_{2}$ adalah $\hat{X}_{3}=120,492+0,446 X_{2}$ hasil perhitungan bersifat linier

\section{Uji Normalitas Galat Taksiran}

Pengujian normalitas data dengan menggunakan uji Liliefors, maka galat taksiran dinyatakan berasal dari populasi berdistribusi normal jika $\mathrm{L}_{\text {hitung }} \leq \mathrm{L}_{\text {tabel }}$ pada taraf signifikansi $\alpha=$ 
0,05. Uji normalitas galat taksiran meliputi $\mathrm{Y}$ atas $\mathrm{X}_{1}, \mathrm{Y}$ atas $\mathrm{X}_{2}, \mathrm{Y}$ atas $\mathrm{X}_{3}, \mathrm{X}_{3}$ atas $\mathrm{X}_{1}, \mathrm{X}_{3}$ atas $\mathrm{X}_{2}$. Hipotesis yang diuji adalah:

$\mathrm{H}_{0}$ : data berasal dari populasi berdistribusi normal

$\mathrm{H}_{1}$ : data berasal dari populasi tidak berdistribusi normal

Berdasarkan perhitungan normalitas data diperoleh hasil pengujian sebagaimana dalam tabel berikut.

Tabel 2 Rangkuman Hasil Uji Normalitas Galat Taksiran

\begin{tabular}{|c|c|c|l|}
\hline Regresi & $\mathbf{L}_{\text {hit }}$ & $\mathbf{L}_{\text {tabel }(\mathbf{0 , 0 5})}$ & \multicolumn{1}{|c|}{ Keterangan } \\
\hline $\mathrm{Y}$ atas $\mathrm{X}_{1}$ & 0.062 & 0.076 & Data Berdistribusi Normal \\
\hline $\mathrm{Y}$ atas $\mathrm{X}_{2}$ & 0.072 & 0.076 & Data Berdistribusi Normal \\
\hline $\mathrm{Y}$ atas $\mathrm{X}_{3}$ & 0.052 & 0.076 & Data Berdistribusi Normal \\
\hline $\mathrm{X}_{3}$ atas $\mathrm{X}_{1}$ & 0.052 & 0.076 & Data Berdistribusi Normal \\
\hline $\mathrm{X}_{3}$ atas $\mathrm{X}_{2}$ & 0.055 & 0.076 & Data Berdistribusi Normal \\
\hline
\end{tabular}

Dari Tabel di atas menunjukkan bahwa semua data berasal dari populasi yang berdistribusi normal karena nilai $\mathrm{L}_{\mathrm{o}}=\mathrm{L}_{\text {hitung }}>\mathrm{L}_{\text {daftar(tabel) }}$ pada $\alpha=0,05$.

\section{Pengujian Hipotesis}

Pengujian hipotesis penelitian menggunakan analisis jalur, berdasarkan model teoritik yang telah dikonstruksi melalui kajian teori, maka ada 2 (dua) persamaan struktural yang terbentuk yaitu:

$$
\mathrm{Y}=\beta_{\mathrm{y} 1} \mathrm{X}_{1}+\beta_{\mathrm{y} 2} \mathrm{X}_{2}+\beta_{\mathrm{y} 3} \mathrm{X}_{3}+\varepsilon_{1} \text { dan } \mathrm{X}_{3}=\beta_{\mathrm{x} 3 \mathrm{x} 1} \mathrm{X}_{1}+\beta_{\mathrm{x} 3 \mathrm{x} 2} \mathrm{X}_{2}+\varepsilon_{2}
$$

Persamaan struktural $\mathrm{Y}=\beta_{\mathrm{y} 1} \mathrm{X}_{1}+\beta_{\mathrm{y} 2} \mathrm{X}_{2}+\beta_{\mathrm{y} 3} \mathrm{X}_{3}+\varepsilon_{1}$ digunakan untuk menguji hipotesis penelitian 1, 2, dan 3. Persamaan struktural $X_{3}=\beta_{\times 3 \times 1} X_{1}+\beta_{\times 3 \times 2} X_{2}+\varepsilon_{2}$ digunakan untuk menguji hipotesis penelitian 4 dan 5.

\section{Persamaan Struktural $Y=\beta_{\mathrm{y} 1} X_{1}+\beta_{\mathrm{y} 2} X_{2}+\beta_{\mathrm{y} 3} X_{3}$}

Persamaan struktural $Y=\beta_{\mathrm{y} 1} X_{1}+\beta_{\mathrm{y} 2} X_{2}+\beta_{\mathrm{y} 3} X_{3}$ menggambarkan pengaruh masingmasing variabel Partisipasi Pelatihan $\left(\mathrm{X}_{1}\right)$, Responsibility $\left(\mathrm{X}_{2}\right)$, dan Motivasi Kerja $\left(\mathrm{X}_{3}\right)$ terhadap Kinerja (Y). Hasil output koefisien $\mathrm{X}_{1}$ yaitu $\beta_{\mathrm{y} 1}, \mathrm{X}_{2}$ yaitu $\beta_{\mathrm{y} 2}$, dan $\mathrm{X}_{3}$ yaitu $\beta_{\mathrm{y} 3}$ seperti pada Tabel 3. 
Nampak pada Tabel 3, koefisien jalur Partisipasi Pelatihan $\left(\mathrm{X}_{1}\right)$ terhadap Kinerja $(\mathrm{Y})$, Responsibility $\left(\mathrm{X}_{2}\right)$ terhadap Kinerja $(\mathrm{Y})$, dan Motivasi Kerja $\left(\mathrm{X}_{3}\right)$ terhadap Kinerja $(\mathrm{Y})$ ditunjukkan oleh nilai-nilai yang ada pada kolom Standardized Coefficients Beta masing-masing 0,406; 0,215; dan 0,360. Jadi diperoleh persamaan struktural pertama yaitu: $\mathrm{Y}=0,406 \mathrm{X}_{1}+$ $0,215 \mathrm{X}_{2}+0,360 \mathrm{X}_{3}$

\section{Tabel 3 Output SPSS untuk Persamaaan Struktural Pertama}

$$
\mathbf{Y}=\beta_{\mathbf{y} 1} \mathbf{X}_{1}+\beta_{\mathbf{y} 2} \mathbf{X}_{2}+\beta_{\mathrm{y} 3} \mathbf{X}_{3}
$$

\begin{tabular}{|c|c|c|c|c|c|c|}
\hline \multicolumn{7}{|c|}{ Coefficients $^{\mathrm{a}}$} \\
\hline & \multirow[t]{2}{*}{ Model } & \multicolumn{2}{|c|}{$\begin{array}{l}\text { Unstandardized } \\
\text { Coefficients }\end{array}$} & \multirow{2}{*}{$\begin{array}{c}\begin{array}{l}\text { Standardized } \\
\text { Coefficients }\end{array} \\
\text { Beta }\end{array}$} & \multirow[t]{2}{*}{$\mathrm{t}$} & \multirow[t]{2}{*}{ Sig. } \\
\hline & & B & Std. Error & & & \\
\hline \multirow[t]{4}{*}{1} & (Constant) & 55.469 & 16.485 & & 3.365 & .001 \\
\hline & Partisipasi Pelatihan & .621 & .094 & .406 & 6.622 & .000 \\
\hline & Responsibility & 277 & .081 & .215 & 3.400 & .001 \\
\hline & Motivasi Kerja & .521 & .096 & .360 & 5.421 & .000 \\
\hline
\end{tabular}

Berdasarkan tabel di atas koefisien jalur Partipasi Pelatihan terhadap Kinerja Kepala Desa adalah $\beta_{\mathrm{yx} 1}=0.406$ dan $t_{\text {hitung }}=6.622$ dengan probability sebagaimana ditunjukkan oleh kolom Sig di atas $(\mathrm{P}) 0.000$ atau $(\mathrm{P}<0.05)$ yang berarti signifikan. Koefisien jalur Responsibility terhadap Kinerja Kepala Desa adalah $\beta_{\mathrm{yx} 1}=0.215$ dan $\mathrm{t}_{\mathrm{hitung}}=3.400$ dengan probability sebagaimana ditunjukkan oleh kolom Sig di atas $(\mathrm{P}) 0.001$ atau $(\mathrm{P}<0.05)$ yang berarti signifikan. Sedangkan Koefisien jalur Motivasi Kerja terhadap Kinerja Kepala Desa adalah $\beta_{\mathrm{yx} 1}=0.360$ dan $\mathrm{t}_{\text {hitung }}=$ 5.421 dengan probability sebagaimana ditunjukkan oleh kolom Sig di atas (P) 0.000 atau (P < $0.05)$ yang berarti signifikan.

Persamaan struktural $\mathrm{Y}=0,406 \mathrm{X}_{1}+0,215 \mathrm{X}_{2}+0,360 \mathrm{X}_{3}$ ini ternyata signifikan karena nilai $\mathrm{F}_{\text {hitung }}=$ 69,622 dengan nilai probabilitas (Sig.) sebesar 0,000. Persamaan struktural ini juga ternyata sangat signifikan (berarti) karena nilai pada kolom (Sig.) ada tanda $a$. Dengan demikian disimpulkan bahwa model persamaan yang menggambarkan pengaruh langsung positip Partisipasi Pelatihan $\left(\mathrm{X}_{1}\right)$, Responsibility $\left(\mathrm{X}_{2}\right)$, Motivasi Kerja $\left(\mathrm{X}_{3}\right)$ terhadap Kinerja Kepala Desa (Y) adalah linier. Hal in nampak pada Tabel 4 berikut. 
Tabel 4. Anava untuk Uji Signifikansi Persamaan Struktur

$$
\mathrm{Y}=\mathbf{0 , 4 0 6 X _ { 1 }}
$$

$$
+0,215 X_{2}+0,360 X_{3}
$$

\begin{tabular}{|c|c|c|c|c|c|c|}
\hline \multicolumn{7}{|c|}{ ANOVA $^{b}$} \\
\hline & Model & Sum of Squares & $\mathrm{df}$ & Mean Square & $\mathrm{F}$ & Sig. \\
\hline \multirow[t]{3}{*}{1} & Regression & 25050.339 & 3 & 8350.113 & 69.622 & $.000^{\mathrm{a}}$ \\
\hline & Residual & 15951.428 & 133 & 119.936 & & \\
\hline & Total & 41001.766 & 136 & & & \\
\hline
\end{tabular}

a. Predictors: (Constant), Partisipasi Pelatihan, Responsibility, Motivasi Kerja.

b. Dependent Variabel: Kinerja

Model persamaan struktural $\mathrm{Y}=0,406 \mathrm{X}_{1}+0,215 \mathrm{X}_{2}+0,360 \mathrm{X}_{3}$ dapat divisualisasikan pada bentuk gambar berikut ini.

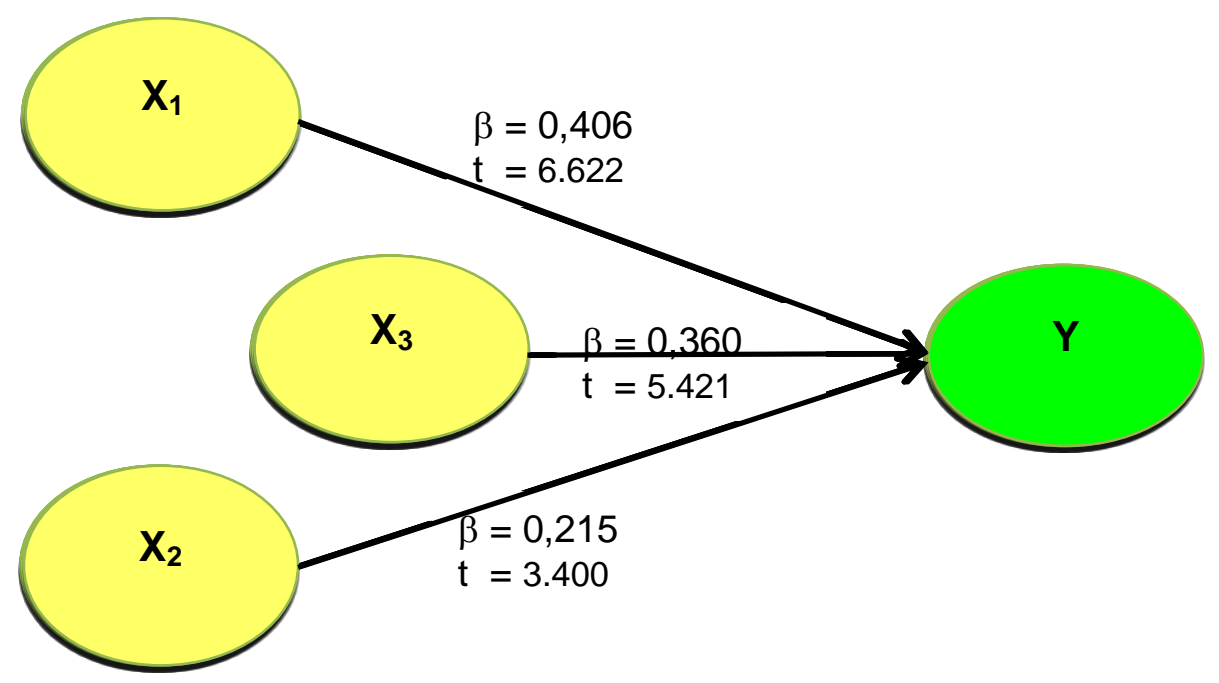

\section{Gambar Model Persamaan Struktural $Y=0,406 X_{1}+0,215 X_{2}+0,360 X_{3}$}

Berdasarkan persamaan struktural ini dijelaskan temuan penelitian untuk pengujian hipotesis pertama sampai ketiga.

\section{a. Pengujian Hipotesis Pertama: Pengaruh langsung Partisipasi Pelatihan terhadap Kinerja Kepala Desa}

Hipotesis pertama berbunyi, "Terdapat pengaruh langsung positif Partisipasi Pelatihan terhadap Kinerja Kepala Desa” dengan hipotesis statistik:

$$
\mathrm{H}_{0}: \beta_{\mathrm{yx} 1} \leq 0 \text { dan } \mathrm{H}_{1}: \beta_{\mathrm{yx} 1}>0
$$


Berdasarkan persamaan struktural pertama diperoleh koefisien jalur Partisipasi Pelatihan $\left(\mathrm{X}_{1}\right)$ terhadap Kinerja Kepala Desa $(\mathrm{Y})$ yakni $\beta_{\mathrm{yx} 1}$ sebesar 0,406. Hasil uji signifikansi koefisien jalur ini diperoleh nilai $\mathrm{t}_{\text {hitung }}$ sebesar 6,622 dan nilai $\mathrm{t}_{\text {tabel }(\alpha=0.05)}=1$. 97. Dengan demikian $\mathrm{t}_{\text {hitung }}>$ $\mathrm{t}_{\text {tabel }}$ yang berarti $\mathrm{H}_{0}$ ditolak. Koefisien jalur antar Partisipasi Pelatihan terhadap Kinerja Kepala Desa signifikan dan nilai probabilitas (Sig.) 0,000 < 0,05 maka koefisien jalur dinyatakan signifikan. Temuan ini memberikan makna bahwa terdapat pengaruh langsung positip Partisipasi Pelatihan terhadap Kinerja Kepala Desa di Kabupaten Gorontalo.

\section{b. Pengujian Hipotesis Kedua: Pengaruh langsung Responsibility terhadap Kinerja Kepala Desa}

Hipotesis kedua berbunyi, "Terdapat pengaruh langsung positif Responsibility terhadap Kinerja Kepala Desa" dengan hipotesis statistik:

$$
\mathrm{H}_{0}: \beta_{\mathrm{yx} 2} \leq 0 \text { dan } \mathrm{H}_{1}: \beta_{\mathrm{yx} 2}>0
$$

Berdasarkan persamaan struktural pertama diperoleh koefisien jalur Responsibility $\left(\mathrm{X}_{2}\right)$ terhadap Kinerja Kepala Desa (Y) yakni $\beta_{\mathrm{yx} 2}$ sebesar 0,215. Hasil uji signifikansi koefisien jalur ini diperoleh nilai $t_{\text {hitung }}$ sebesar 3,400 dan nilai $t_{\text {tabel }(\alpha=0.05)}=1$. 97. Dengan demikian $t_{\text {hitung }}>t_{\text {tabel }} l$ yang berarti $\mathrm{H}_{0}$ ditolak. Koefisien jalur antar Responsibility terhadap Kinerja Kepala Desa signifikan dan nilai probabilitas $($ Sig.) $=0,001<0,05$ maka koefisien jalur dinyatakan signifikan. Temuan ini memberikan makna bahwa terdapat pengaruh langsung positip Responsibility terhadap Kinerja Kepala Desa di Kabupaten Gorontalo.

\section{c. Pengujian Hipotesis Ketiga: Pengaruh langsung Motivasi Kerja terhadap Kinerja Kepala Desa}

Hipotesis ketiga berbunyi, “Terdapat pengaruh langsung positif Motivasi Kerja terhadap Kinerja Kepala Desa” dengan hipotesis statistik:

$$
\mathrm{H}_{0}: \beta_{\mathrm{yx} 3} \leq 0 \text { dan } \mathrm{H}_{1}: \beta_{\mathrm{yx} 3}>0
$$

Berdasarkan persamaan struktural pertama diperoleh koefisien jalur Motivasi Kerja $\left(\mathrm{X}_{3}\right)$ terhadap Kinerja Kepala Desa (Y) yakni $\beta_{\mathrm{yx} 3}$ sebesar 0,360. Hasil uji signifikansi koefisien jalur ini diperoleh nilai $t_{\text {hitung }}$ sebesar 5,421 (Tabel 3) dan nilai $t_{\text {tabel }(\alpha=0.05)}=1$. 97. Dengan demikian $t_{\text {hitung }}>t_{\text {tabe }} l$ yang berarti Ho ditolak. Koefisien jalur antar Motivasi Kerja terhadap Kinerja Kepala Desa signifikan dan nilai probabilitas $($ Sig. $)=0,001<0,05$ maka koefisien jalur dinyatakan signifikan. Temuan ini memberikan makna bahwa terdapat pengaruh langsung positip Motivasi Kerja terhadap Kinerja Kepala Desa di Kabupaten Gorontalo. 


\section{Persamaan Struktural $X_{3}=\beta_{x 3 \times 1} X_{1}+\beta_{x 3 \times 2} X_{2}$}

Persamaan strktural $\mathrm{X}_{3}=\beta_{\mathrm{x} 3 \times 1} \mathrm{X}_{1}+\beta_{\mathrm{x} 3 \times 2} \mathrm{X}_{2}$ menggambarkan pengaruh masing-masing variabel Partisipasi Pelatihan $\left(\mathrm{X}_{1}\right)$ dan Responsibility $\left(\mathrm{X}_{2}\right)$ terhadap Motivasi Kerja $\left(\mathrm{X}_{3}\right)$. Hasil output koefisien $\mathrm{X}_{1}$ yaitu $\beta_{\mathrm{x} 3 \mathrm{x} 1}$ dan $\mathrm{X}_{2}$ yaitu $\beta_{\mathrm{x} 3 \mathrm{x} 2}$ seperti pada Tabel 5 .

\section{Tabel 5 Output SPSS untuk Persmaaan Struktural Kedua}

$$
\mathbf{X}_{3}=\boldsymbol{\beta}_{\mathrm{x} 3 \times 1} \mathbf{X}_{1}+\boldsymbol{\beta}_{\mathbf{3} 3 \times 2} \mathbf{X}_{2}
$$

\begin{tabular}{|c|c|c|c|c|c|c|}
\hline \multicolumn{7}{|c|}{ Coefficients $^{\mathrm{a}}$} \\
\hline & & \multicolumn{2}{|c|}{$\begin{array}{c}\text { Unstandardized } \\
\text { Coefficients }\end{array}$} & $\begin{array}{l}\text { Standardized } \\
\text { Coefficients }\end{array}$ & & \\
\hline \multicolumn{2}{|c|}{ Model } & B & Std. Error & Beta & $\mathrm{t}$ & Sig. \\
\hline \multirow[t]{3}{*}{1} & (Constant) & 79.543 & 13.115 & & 6.065 & .000 \\
\hline & Partisipasi Pelatihan & .332 & .079 & .314 & 4.194 & .000 \\
\hline & Responsibility & .350 & .067 & .393 & 5.248 & .000 \\
\hline
\end{tabular}

Mengacu pada tabel di atas koefisien jalur Partipasi Pelatihan terhadap Motivasi Kerja Kepala Desa adalah $\beta_{\mathrm{yx} 1}=0.314$ dan $t_{\text {hitung }}=4.194$ dengan probability sebagaimana ditunjukkan oleh kolom Sig di atas $(\mathrm{P}) 0.000$ atau $(\mathrm{P}<0.05)$ yang berarti signifikan. Koefisien jalur Responsibility terhadap Motivasi Kerja Kepala Desa adalah $\beta_{\mathrm{yx} 1}=0.393$ dan $\mathrm{t}_{\text {hitung }}=5.248$ dengan probability sebagaimana ditunjukkan oleh kolom Sig di atas $(\mathrm{P}) 0.000$ atau $(\mathrm{P}<0.05)$ yang berarti signifikan.

Koefisien jalur Partisipasi Pelatihan $\left(\mathrm{X}_{1}\right)$ terhadap Motivasi Kerja $\left(\mathrm{X}_{3}\right)$ dan Responsibility $\left(\mathrm{X}_{2}\right)$ terhadap Motivasi Kerja $\left(\mathrm{X}_{3}\right)$ ditunjukkan oleh nilai-nilai yang ada pada kolom Standardized Coefficients Beta masing-masing 0,314 dan 0,393. Jadi diperoleh persamaan struktural kedua yaitu: $X_{3}=0,314 X_{1}+0,393 X_{2}$.

Persamaan struktural ini ternyata signifikan karena nilai $F_{\text {hitung }}=34,273$ dengan nilai probabilitas (Sig.) sebesar $0,000^{a}$. Persamaan struktural ini juga ternyata sangat signifikan (berarti) karena nilai pada kolom (Sig.) ada tanda $a$. Hasil output SPSS seperti pada Tabel 6. 
Tabel 6 Anava untuk Uji Signifikansi Persamaan Struktural

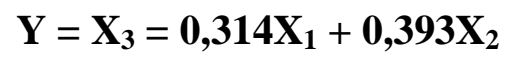

\begin{tabular}{|l|l|r|r|r|r|r|}
\hline \multicolumn{7}{|c|}{ ANOVA $^{\mathrm{b}}$} \\
\hline \multicolumn{1}{|l|}{ Model } & Sum of Squares & \multicolumn{1}{c|}{ df } & Mean Square & F & \multicolumn{1}{c|}{ Sig. } \\
\hline 1 & Regression & 6632.392 & 2 & 3316.196 & 34.273 & $.000^{\mathrm{a}}$ \\
\cline { 2 - 8 } & Residual & 12965.506 & 134 & 96.758 & & \\
\cline { 2 - 8 } & Total & 19597.898 & 136 & & & \\
\hline
\end{tabular}

a. Predictors: (Constant), Responsibility, Partisipasi Pelatihan

b. Dependent Variable: Motivasi Kerja

Model persamaan struktural $\mathrm{X}_{3}=0,314 \mathrm{X}_{1}+0,393 \mathrm{X}_{2}$ dapat divisualisasikan pada bentuk gambar berikut ini.

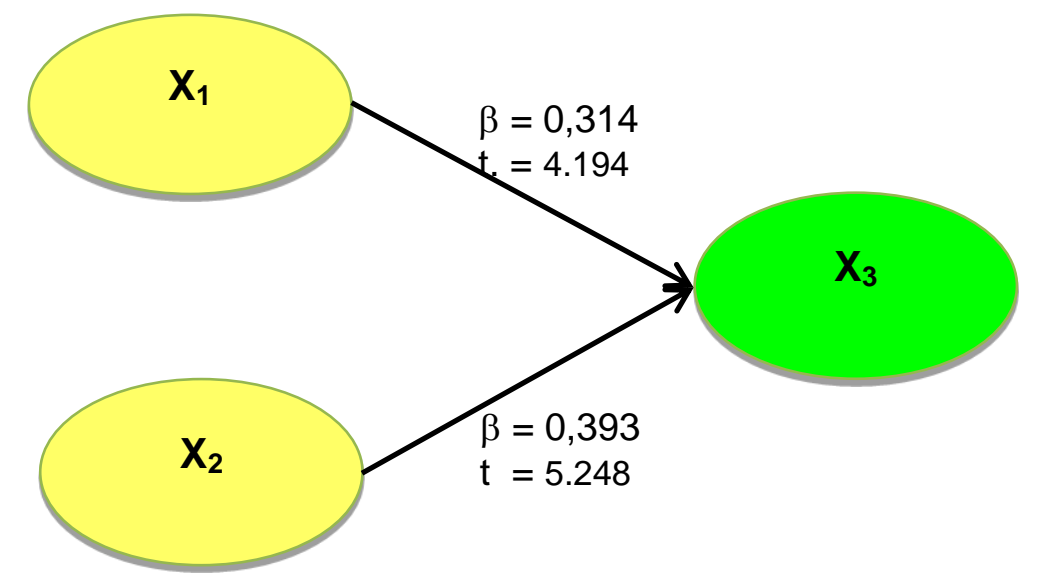

Gambar Model Persamaan Struktural $X_{3}=0,314 X_{1}+0,393 X_{2}$

Berdasarkan persamaan struktural ini dijelaskan temuan penelitian untuk pengujian hipotesis keempat dan kelima.

\section{d. Pengujian Hipotesis Keempat: Pengaruh langsung Partisipasi Pelatihan terhadap Motivasi Kerja Kepala Desa}

Hipotesis keempat berbunyi, “Terdapat pengaruh langsung positif Partisipasi Pelatihan terhadap Motivasi Kerja Kepala Desa” dengan hipotesis statistik:

$$
\text { Ho : } \quad \beta_{\mathrm{x} 3 \mathrm{x} 1} \leq 0 \text { dan } \mathrm{H} 1 \quad: \beta_{\mathrm{x} 3 \mathrm{x} 1}>0
$$


Berdasarkan persamaan struktural kedua diperoleh koefisien jalur Partisipasi Pelatihan $\left(\mathrm{X}_{1}\right)$ terhadap Motivasi Kerja $\left(\mathrm{X}_{3}\right)$ yakni $\beta_{\mathrm{x} 3 \times 1}$ sebesar 0,314. Hasil uji signifikansi koefisien jalur ini diperoleh nilai $t_{\text {hitung }}$ sebesar 4,194 (Tabel 4.24) dan nilai $t_{\text {tabel }(\alpha=0.05)}=1$. 97. Dengan demikian $t_{\text {hitung }}>t_{\text {tabel }}$ yang berarti Ho ditolak. Koefisien jalur antar Partisipasi Pelatihan terhadap Motivasi Kerja Kepala Desa signifikan dan nilai probabilitas (Sig.) sebesar 0,000. Karena nilai probabilitas $($ Sig. $)=0,000<0,05$ maka koefisien jalur dinyatakan signifikan. Temuan ini memberikan makna bahwa terdapat pengaruh langsung positip Partisipasi Pelatihan terhadap Motivasi Kerja Kepala Desa di Kabupaten Gorontalo.

\section{e. Pengujian Hipotesis Kelima: Pengaruh langsung Responsibility terhadap Motivasi Kerja Kepala Desa}

Hipotesis kelima berbunyi, “Terdapat pengaruh langsung positif Responsibility terhadap Motivasi Kerja Kepala Desa” dengan hipotesis statistik:

$$
\text { Ho } \quad: \quad \beta_{\times 3 \times 2} \leq 0 \text { dan } \mathrm{H} 1 \quad: \beta_{\times 3 \times 2}>0
$$

Berdasarkan persamaan struktural kedua diperoleh koefisien jalur Responsibility $\left(\mathrm{X}_{2}\right)$ terhadap Motivasi Kerja $\left(\mathrm{X}_{3}\right)$ yakni $\beta_{\mathrm{x} 3 \mathrm{x} 1}$ sebesar 0,393. Hasil uji signifikansi koefisien jalur ini diperoleh nilai $\mathrm{t}_{\text {hitung }}$ sebesar 5,248 (Tabel 5) dan nilai $\mathrm{t}_{\mathrm{tabel}(\alpha=0.05)}=1$. 97. Dengan demikian $\mathrm{t}_{\text {hitung }}>\mathrm{t}_{\text {tabe }} \mathrm{l}$ yang berarti $\mathrm{H}_{0}$ ditolak. Koefisien jalur antar Responsibility terhadap Motivasi Kerja Kepala Desa signifikan dan nilai probabilitas (Sig.) sebesar 0,000. Karena nilai probabilitas (Sig.) $=0,000<0,05$ maka koefisien jalur dinyatakan signifikan. Temuan ini memberikan makna bahwa terdapat pengaruh langsung positip Responsibility terhadap Motivasi Kerja Kepala Desa di Kabupaten Gorontalo.

Rangkuman hasil pengujian keseluruhan hipotesis penelitian dirangkum pada Tabel 7.

Tabel 7 Ringkasan Hasil Pengujian Hipotesis Penelitian

\begin{tabular}{|c|c|c|c|c|c|c|}
\hline \multicolumn{2}{|c|}{ Koefisien jalur } & $t_{\text {hitung }}$ & Probabilitas & $t_{\text {tabel }}$ & Keberartian & Kesimpulan \\
\hline$\beta_{\mathrm{yx} 1}$ & 0,406 & 6.622 & 0,000 & \multirow{5}{*}{1.97} & Signifikan & Berpengaruh langsung positif \\
\hline$\beta_{\mathrm{yx} 2}$ & 0,215 & 3,400 & 0,001 & & Signifikan & Berpengaruh langsung positif \\
\hline$\beta_{\mathrm{yx} 3}$ & 0,360 & 5,421 & 0,000 & & Signifikan & Berpengaruh langsung positif \\
\hline$\beta_{x 3 \times 1}$ & 0,314 & 3.454 & 0,000 & & Signifikan & Berpengaruh langsung positif \\
\hline$\beta_{\times 3 \times 2}$ & 0,393 & 4.117 & 0,000 & & Signifikan & Berpengaruh langsung positif \\
\hline
\end{tabular}




\section{Pembahasan}

\section{Pengaruh Langsung Positif Partisipasi Pelatihan $\left(\mathbf{X}_{1}\right)$ terhadap Kinerja Kepala Desa (Y)}

Hasil analisis membuktikan adanya prngaruh positif Partisipasi Pelatihan terhadap kinerja Kepala Desa. Nilai koefisien standar (beta) yang dihasilkan adalah 0,406 dengan $t_{\text {hitung }} 6,622$.

Pengujian hipotesis pertama memberikan penegasan dan interprestasi secara empiris tentang pentingnya Partisipasi Pelatihan terhadap Kinerja, sehingga hal ini dapat dimengerti bahwa Partisipasi Pelatihan berpengaruh langsung positif terhadap Kinerja Kepala Desa. Berdasarkan hasil pengujian hipotesis tersebut, menunjukkan bahwa terdapat Pengaruh langsung positif Partisipasi Pelatihan $\left(\mathrm{X}_{1}\right)$ terhadap Kinerja Kepala Desa (Y). Temuan tersebut sesuai dengan teori yang dikemukakan Armstrong (2001:16) yang mengatakan dua diantara faktor yang mempengaruhi Kinerja adalah: Pertama, Faktor personal yang meliputi berbagai keterampilan individu, kompetensi, kecerdasan, kemandirian, kreativitas, motivasi, keyakinan; dan Kedua, Faktor kepemimpinan yang berkualitas dan pemberian motivasi, bimbingan dan dorongan. Keterampilan dan berbagai kompetensi yang dibutuhkan dalam melaksanakan tugas manajerial dapat diperoleh melalui Partisipasi Pelatihan.

Mahapatro mengatakan bahwa Pelatihan merupakan tindakan meningkatkan pengetahuan dan keterampilan untuk melakukan pekerjaan tertentu. Pelatihan melibatkan bagian keterampilan yang dibutuhkan untuk melaksanakan pekerjaan-pekerjaan spesifik. Tujuannya untuk mencapai perubahan dalam perilaku dari keikutsertaannya dalam Pelatihan dan membangun kemampuan melakukan pekerjaan-pekerjaan dengan baik. Pada intinya Partisipasi Pelatihan harus dapat melakukan perubahan positif dalam hal (1) pengetahuan, (2) keterampilan dan (3) sikap pekerja. Dengan pengetahuan, keterampilan dan sikap itu maka melahirkan kinerja. Sebab Kinerja mensyaratkan keterampilan kerja. Seseorang dapat melakukan pekerjaan jika yang bersangkutan terampil dalam pekerjaan itu.

Ivancevich menyatakan bahwa usaha untuk meningkatkan kinerja pegawai dalam pekerjaannya sekarang atau dalam pekerjaan lain yang akan dijabatnya segera adalah Pelatihan. Sebab Ivancevich meyakini bahwa Pelatihan (training) sebagai proses sistematis mengubah perilaku kerja seorang/sekelompok dalam usaha meningkatkan kinerja organisasi. Pelatihan terkait dengan keterampilan dan kemampuan yang diperlukan untuk pekerjaan yang sekarang 
dilakukan. Pelatihan berorientasi ke masa sekarang dan membantu untuk menguasai keterampilan dan kemampuan (kompetensi) yang spesifik agar berhasil dalam mengerjakan tugas. Pernyataan Ivancevich itu menggambarkan bahwa Kinerja yang merupakan tolok ukur keberhasilan dalam melakukan suatu pekerjaan sangat terkait dengan peran individu dalam organisasi, Kinerja adalah serangkaian perilaku atau kegiatan individu yang sesuai dengan harapan atau keinginan organisasi tempat bekerja

Salah satu yang terkait dengan perilaku individu tersebut meminjam istilah Pynes adalah pelatihan dan pengembangan karyawan. Sebab suatu tindakan yang dilakukan harus dicapai oleh organisasi menurut Yukl, harus didukung oleh kemampuan diri setiap individu yang terlibat didalamnya. Kinerja kata Yukl tidak akan terbentuk jika iklim suatu organisasi tidak mendukung dengan upaya pemberian kesempatan agar dapat menggunakan kemampuan dan keterampilan personel yang ada di lingkungan kerja

\section{Pengaruh Langsung Positif Responsibility $\left(\mathrm{X}_{2}\right)$ terhadap Kinerja Kepala Desa (Y)}

Hasil analisis membuktikan adanya prngaruh positif Responsibility terhadap kinerja Kepala Desa. Nilai koefisien standar (beta) yang dihasilkan adalah 0,215 dengan $t_{\text {hitung. 3,400 }}$

Pengujian hipotesis kedua menyatakan bahwa Responsibility $\left(\mathrm{X}_{2}\right)$ berpengaruh langsung positif terhadap Kinerja Kepala Desa (Y). Hal ini telah sesuai dengan teori yang dikemukakan Gibson bahwa kinerja merupakan tingkat keberhasilan dalam melaksanakan tugas serta kemampuan untuk mencapai tujuan yang telah ditetapkan kinerja dinyatakan baik dan sukses jika tujuan yang diinginkan dapat tercapai dengan baik, terutama pada kualitas dan efisiensi dari kriteria keefektifan. Pada pandangan yang sama, Cascio mengemukakan bahwa kinerja mengacu pada penyelesaian tugas, sedangkan penilaian kinerja adalah deskripsi yang sistematis mengenai kekuatan dan kelemahan yang relevan dengan pekerjaan dari individu atau kelompok. Kinerja yang dikaitkan dengan pengembangan individu dan organisasi terhadap kontribusi tugas dalam peningkatan kualitas kerja, dimana Responsibity atau Tanggung Jawab individu merupakan keseimbangan antara aktivitas dengan proses emosi untuk membangun dan merespon untuk bekerja sama, sehingga kerja setiap orang dalam kelompok atau organisasi dalam mengembangkan karier. Pendapat Cascio senada juga dengan dikemukakan Newston bahwa kinerja merupakan kuantitas dan kualitas produk atau jasa, serta tingkat pelayanan pelanggan.

Dari teori-teori itu nampak bahwa Kinerja bukan hanya kualitas tetapi juga merupakan kuantitas kerja seseorang. Kinerja merupakan alasan untuk menciptakan pekerjaan tertentu di 
tempat kerja dan menjadi dasar bagi keseluruhan produktivitas organisasi. Semakin tinggi target Kinerja yang harus diselesaikan sebesar itu pula ukuran Tanggung Jawab yang harus diselesaikan. Oleh sebab itu ukuran Tanggung Jawab secara tepatnya dipandang sebagai ukuran Kinerja.

Ivancevic \& Collin yang menyatakan bahwa Responsibility merupakan jumlah pekerjaan yang orang harus dilakukan dan diselesaikan. Ukuran Tanggung Jawab berada pada pekerjaan yang dilakukan serta ukuran sasaran yang diselesaikan. Tanggung jawab merepresentasikan aliran kasus dalam sebuah sistem atau jumlah pelanggan yang terbiasa dilayani. Ukuran Tanggung Jawab dapat merepresentasikan sumber daya yang dituntut atau jaminan pekerjaan yang harus dilaksanakan dalam sebuah sistem produksi. Dari pendapat ahli tersebut nampak bahwa Responsibility mencakup sejumlah pekerjaan, kompleksitasnya, maupun urutanurutannya. Karena dalam Responsibility mensyaratkan keserasian antara pekerjaan yang dilaksanakan dengan rencana kerja sebagai langkah yang tepat dalam mensinkronkan antara misi organisasi dengan aspirasi pekerja. Pernyataan ini memaknakan Responsibility sebagai keseluruhan waktu yang digunakan oleh pegawai dalam melakukan kegiatan selama waktu pekerjaan berlangsung. Wickens menyebut Responsibility sebagai hubungan antara penawaran dan permintaan sumber daya tugas. Hancock dan Caird mengkonseptualisasikan Responsibility ke dalam tiga dimensi yaitu: (1) waktu untuk melaksanakan tindakan, (2) jangkauan terhadap tujuan yang diinginkan, dan (3) tingkat usaha yang dibutuhkan untuk mencapai tujuan diinginkan. Jadi Responsibility turut mempengaruhi secara positif Kinerja.

\section{Pengaruh Langsung Positif Motivasi Kerja $\left(\mathbf{X}_{3}\right)$ terhadap Kinerja $(\mathbf{Y})$.}

Hasil analisis membuktikan adanya pengaruh positif Responsibility terhadap Kinerja Kepala Desa. Nilai koefisien standar (beta) yang dihasilkan adalah 0,360 dengan $t_{\text {hitung. }}$ 5,421.

Pengujian hipotesis ketiga menyatakan bahwa terdapat pengaruh langsung positif Motivasi Kerja $\left(\mathrm{X}_{3}\right)$ terhadap Kinerja Kepala Desa (Y). Hal ini telah sesuai dengan teori kinerja sebagaimana dikemukakan Demitry sebagai output individu atau tim yang diperoleh dari pelaksanaan tugas berdasarkan deskripsi kerja dimana mereka diberi penghargaan berdasarkan hasil penilaian kinerjanya. Amstrong mengatakan bahwa untuk mencapai output yang ditetapkan maka dibutuhkan motivasi kerja yang mencakup (1) Petunjuk-Apa yang membuat orang mencoba melakukan; (2) Upaya-Seberapa sungguh orang mencoba; dan (3) KetekunanSeberapa lama seseorang untuk mencoba terus. Motivasi dapat digambarkan sebagai perilaku 
mencapai tujuan. Tujuannya adalah kinerja sedangkan perilaku yang digunakan untuk mencapainya adalah motivasi itu sendiri. Dengan demikian capaian kinerja sangat tergantung pada kekuatan dorongan seseorang melaksanakan pekerjaan.

Motivasi adalah sesuatu yang mendorong pelaku untuk beraksi atau mendukung memberi tindakan nyata untuk menyatakan aksinya. Berarti ada dorongan dari pribadi karena kemauannya dan disebabkan dari dalam diri dan lingkungan kerja. Wyatt Wesley mengatakan motivasi merupakan bentuk tingkah laku manusia yang sesuai dengan keinginan pencapaian goal yang memberi harapan yang diinginkan. Realitasnya dapat dijelaskan pada konteks pendapatan/gaji yang didapatkan dari kinerja pekerja, merupakan salah satu faktor pendorong motivasi kerja pekerja, sehingga kinerja dipengaruhi faktor-faktor yang mendorong motivasi pekerja. Dikatakan motivasi karena berkaitan dengan pekerjaan itu sendiri seperti kecocokan pada pekerjaan, pekerjaan maupun target sesuai dengan yang diharapkan, rasa tanggung jawab karena merasa dipandang penting, kesempatan berkembang, dan kesempatan karir. Dari pendapat ahli tersebut nampak bahwa Motivasi Kerja yang berpengaruh langsung positif terhadap Kinerja Kepala Desa memiliki basis teoretik yang kokoh.

\section{Pengaruh Langsung Positif Partisipasi Pelatihan terhadap Motivasi Kerja}

Hasil analisis membuktikan adanya prngaruh positif Responsibility terhadap kinerja Kepala Desa. Nilai koefisien standar (beta) yang dihasilkan adalah 0,314 dengan $t_{\text {hitung. }}$ 3,454.

Pengujian hipotesis keempat menyatakan bahwa terdapat pengaruh langsung positif Partisipasi Pelatihan $\left(\mathrm{X}_{1}\right)$ terhadap Motivasi Kerja $\left(\mathrm{X}_{3}\right)$. Temuan penelitian ini telah sesuai dengan pernyataan bahwa Motivasi dapat digambarkan sebagai perilaku mencapai tujuan. Motivasi dicirikan dalam bentuk fenomena individu dimana setiap orang dipandang unik dan semua teori motivasi memungkinkan untuk menunjukkan keunikan ini dalam cara berbeda. Motivasi terdiri dari beragam versi. Dua faktor yang paling penting adalah: (i) apa yang membuat orang-orang aktif (bergairah), dan

(ii) kekuatan individu terlibat dalam perilaku yang diinginkan (arah atau pilihan perilaku).

Motivasi umumnya digunakan untuk menggambarkan upaya atau pendorong yang menempatkan seseorang dalam sebuah kegiatan. Mitchell mengatakan bahwa motivasi sebagai derajat individu ingin dan memilih terlibat dalam perilaku tertentu. Menggarisbawahi konsep tersebut di atas maka motivasi adalah gabungan dari kekuatan pendorong dalam diri seseorang yang menjadikan mereka mencapai beberapa tujuan dalam rangka memenuhi beberapa kebutuhan 
atau ekspektasi. Salah satu kekuatan yang menjadi alat pendorong seseorang untuk mencapai tujuan mereka adalah kemampuan dan kompetensi individu. Sedangkan kemampuan dan kompetensi individu dapat dibentuk melalui sebuah proses perubahan perilaku yang secara sistematis berdampak pada perubahan pola sikap, keterampilan dan pengetahuan yang dituntut dari seseorang dalam hal melaksanakan tugas atau pekerjaan secara tepat. Mathis menyatakan bahwa keikutsertaan dalam pelatihan adalah sebuah proses dimana orang berupaya mencapai kemampuan tertentu untuk membantu mencapai tujuan organisasi. Oleh karena itu, proses ini terikat dengan berbagai tujuan organisasi, pelatihan dapat dipandang secara sempit maupun luas. Secara terbatas, Partisipasi Pelatihan mengarahkan para pegawai berbagai pengetahuan spesifik dan dapat diserap serta keterampilan yang digunakan dalam pekerjaan mereka saat ini. Pada konteks ini Partisipasi Pelatihan merupakan wahana awal untuk membangun Motivasi. Karena Pelatihan sarat dengan muatan pengetahuan, inspirasi dan informasi yang pada akhirnya akan melahirkan kemampuan untuk melakukan dan berbuat. Dengan modal kemampuan melakukan dan berbuat itulah maka ada dorongan untuk melakukan. Disinilah pandangan tentang Partisipasi Pelatihan dengan motivasi instrinsik menemukan pengaruh yang kuat.

Dari bahasan di atas nampak paling tidak ada 3 hal penting yang menjadi sasaran Partisipasi Pelatihan. Pertama adalah pencapaian kemampuan tertentu yang menjadi tuntutan organisasi. Setiap organisasi menghendaki adanya ambang batas kemampuan personal yang dipersyaratkan dalam mencapai tujuan. Tanpa kemampuan tersebut maka tujuan organisasi tidak akan tercapai. Kedua, dalam proses pencapaian tujuan itu, maka keikutsertaan dalam Pelatihan menjadi alat intervensi untuk meningkatkan kemampuan. Disinilah kemampuan tidak sekedar dikuasai, melainkan harus dapat diterapkan dalam proses-proses kerja. Dan Ketiga, dengan kemampuan yang dimiliki melalui proses Pelatihan dan kemudian diterapkan dalam prosesproses kerja, maka diharapkan akan tercipta keberhasilan kerja. Ketiga sasaran di atas menjadi energi bagi seseorang untuk melakukan pekerjaan atau tugas-tugasnya. Energi itulah yang kemudian disebut sebagai Motivasi Kerja.

\section{Pengaruh Langsung Positif Responsibility $\left(\mathbf{X}_{2}\right)$ terhadap Motivasi Kerja $\left(\mathbf{X}_{3}\right)$}

Hasil analisis membuktikan adanya pengaruh positif Responsibility terhadap Kinerja Kepala Desa. Nilai koefisien standar (beta) yang dihasilkan adalah 0,393 dengan $t_{\text {hitung. }}$ 4,117.

Pengujian hipotesis kelima menyatakan bahwa terdapat pengaruh langsung positif Responsibility $\left(\mathrm{X}_{2}\right)$ terhadap Motivasi Kerja $\left(\mathrm{X}_{3}\right)$. Terkait dengan temuan tersebut, Motivasi 
Kerja dipicu oleh informasi Tanggung Jawab. Sebagai salah satu informasi strategis yang dibutuhkan untuk memampukan eksekusi strategi organisasi, maka Responsibility pada tingkat pemegang jabatan atau unit kerja menjadi informasi tentang rata-rata penggunaan waktu kerja untuk menyelesaikan tugas-tugas kedinasan agar memenuhi target yang telah ditetapkan. Responsibility tersebut merupakan hasil dari rangkaian aktivitas yang dilakukan oleh pemangku jabatan atau kumpulan pekerja pada suatu unit kerja untuk menyelesaikan misi tugas. Tanggung Jawab adalah jumlah pekerjaan yang orang harus lakukan. Ukuran Tanggung Jawab berada pada pekerjaan yang dilakukan, ukuran, dan sasaran yang diselesaikan. Penambahan Tanggung Jawab pada level tertentu akan mendorong seseorang untuk segera menyelesaikan pekerjaan. Dalam konteks ini maka Responsibility menjadi faktor yang sangat mempengaruhi Motivasi Kerja, terutama pada bentuk organisasi Pemerintahan Desa yang sarat dengan komando (perintah). Pada kasus yang terjadi dilevel pemerintah, biasanya Tanggung Jawab menjadi faktor yang mempengaruhi secara positif terhadap Motivasi Kerja. Karena diorganisasi tersebut Kepala Desa yang berada pada level pemerintahan yang dipilih langsung oleh masyarakat mendapatkan ruang ekspresi yang lebih luas untuk kemudian diharapkan dapat meningkatkan publisitas dimasyarakat. Tidak sedikit ditemukan dilapangan bahwa Kepala Desa absen ke Kantor Desa karena alasan tidak adanya tugas yang harus diselesaikan. Tetapi banyak Kepala Desa yang aktif dikantor karena ada tugas-tugas besar dan banyak yang harus diselesaikan. Lebih spesifik lagi banyak Kepala Desa yang aktif menyelesaikan tugas-tugasnya yang besar dan banyak karena kepatuhan kepada atasan seperti Bupati dan Camat. Karena kedua atasan tersebut memiliki power coerchive kekuasaan formal untuk memberi sanksi. Atas dasar itu Responsibility memiliki pengaruh langsung positif terhadap Motivasi Kerja.

Responsibility terdiri dari dua aspek penting, yakni Tanggung Jawab mental (moral) dan Tanggung Jawab fisik. Tanggung Jawab mental merupakan perhitungan Pekerjaan dengan mempertimbangkan aspek mental (moral). Pengukuran Tanggung Jawab mental dapat dilakukan dengan dua cara yaitu pengukuran secara objektif dapat dilakukan dengan beberapa anggota tubuh. Pengukuran Tanggung Jawab mental secara subjektif merupakan teknik pengukuran yang paling banyak digunakan karena mempunyai tingkat validitas yang tinggi dan bersifat langsung dibandingkan dengan pengukuran lain. Pengukuran Tanggung Jawab mental secara subjektif memiliki tujuan yaitu untuk menentukan skala pengukuran terbaik berdasarkan perhitungan eksperimental, menentukan perbedaan skala untuk jenis pekerjaan dan mengidentifikasi faktor Tanggung Jawab yang berhubungan secara langsung dengan tanggung jawab moral. Faktor lain 
yang mempengaruhi Tanggung Jawab mental seseorang dalam suatu pekerjaan antara lain jenis pekerjaan, situasi pekerjaan waktu respon, waktu penyelesaian yang tersedia dan faktor individu (tingkat motivasi, keahlian, kelelahan, kejenuhan dan toleransi performansi yang diijinkan). Dalam psikologi kerja dibahas masalah-masalah yang berkaitan dengan kejiwaan yang dijumpai pada tempat kerja yaitu menyangkut faktor-faktor diri, sedangkan faktor dalam diri antara lain attitude, jenis kelamin, usia, sifat atau kepribadian, sistem nilai, karakteristik fisik, motivasi, minat, pendidikan dan pengalaman.

Berdasarkan pembahasan yang dikemukakan di atas, maka dapat dikemukakan bahwa temuan penelitian yang menyatakan pengaruh langsung positif Responsibility (Tanggung Jawab) terhadap Motivasi Kerja memiliki basis teoritikal yang kokoh.

\section{A. Kesimpulan Penelitian}

Berdasarkan hasil-hasil penelitian dan pembahasan sebagaimana dijelaskan pada Bab sebelumnya maka dapat dirumuskan kesimpulan penelitian sebagai berikut.

1. Partisipasi Pelatihan berpengaruh langsung positif terhadap Kinerja Kepala Desa. Artinya semakin banyak Pelatihan yang diikuti mengakibatkan peningkatan Kinerja Kepala Desa.

2. Responsibility berpengaruh langsung positif terhadap Kinerja Kepala Desa. Artinya Tanggung Jawab akan meningkatkan Kinerja Kepala Desa.

3. Motivasi Kerja berpengaruh langsung positif terhadap Kinerja Kepala Desa. Artinya peningkatan Motivasi Kerja akan mengakibatkan peningkatan Kinerja Kepala Desa

4. Partisipasi Pelatihan berpengaruh langsung positif terhadap Motivasi Kerja. Artinya Pelatihan akan meningkatkan Motivasi Kerja Kepala Desa.

5. Responsibility berpengaruh langsung positif terhadap Motivasi Kerja Kepala Desa. Artinya Tanggung Jawab akan berakibat pada peningkatan Motivasi Kerja Kepala Desa.

\section{B. Implikasi Penelitian}

Mengacu pada rumusan kesimpulan di atas, maka dapat dikemukakan implikasiimplikasi penelitian sebagai berikut.

1. Pengaruh langsung positif Partisipasi Pelatihan terhadap Kinerja Kepala Desa. Artinya peningkatan Kinerja Kepala Desa diawali dengan pemberian kesempatan untuk mengikuti Pelatihan bagi Kepala Desa. Partisipasi Pelatihan tersebut dapat dilakukan melalui pendelegasian tugas mengikuti pelatihan yang terkait dengan tugas-tugas 
kepemerintahanan dan penyelenggaraan pelayanan publik serta pembangunan, disamping menyelenggarakan pelatihan yang sama pada level Pemerintah Kecamatan dan Kabupaten.

2. Pengaruh Langsung positif Responsibility terhadap Kinerja Kepala Desa. Artinya peningkatan Kinerja Kepala Desa perlu diawali dengan peningkatan Tanggung Jawab secara terencana. Hal itu dapat dilakukan melalui serangkaian tindakan pendelegasian kewenangan, pembagian kewenangan secara jelas dan tegas antar Pemerintah Kecamatan dan Desa termasuk pemerintah Kabupaten dan Desa.

3. Pengaruh Langsung Motivasi Kerja terhadap Kinerja Kepala Desa. Artinya bahwa untuk meningkatkan Kinerja Kepala Desa harus didahului dengan meningkatkan Motivasi Kerja. Hal ini dapat dilaksanakan melalui program-program terkait pemberian insentif yang layak, peningkatan kesejahteraan dan maslahat-maslahat lainnya.

4. Pengaruh Langsung Partisipasi Pelatihan terhadap Motivasi Kerja. Artinya peningkatan Motivasi Kerja harus diawali dengan pemberian Pelatihan bagi Kepala Desa. Partisipasi Pelatihan dalam konteks peningkatan Motivasi Kerja dapat dilakukan melalui berbagai kegiatan diantaranya adalah mengikutsertakan dalam pelatihan-pelatihan formal dan informal baik yang dilaksanakan secara internal maupun melibatkan pihak eksternal yang terkait dan memiliki relevansi tugas sebagai Kepala Desa.

5. Pengaruh Langsung Responsibility terhadap Motivasi Kerja. Artinya peningkatan Motivasi Kerja dapat didahului dengan peningkatan Tanggung Jawab. Upaya-upaya yang terkait dengan peningkatan Tanggung Jawab adalah pendelegasian kewenangan, pembagian tugas yang jelas dan tegas antara Pemerintahan Desa dan Kecamatan, pembagian kewenangan antara Pemerintah Kabupaten dengan Pemerintah Desa, pemberian otonomi pengelolaan anggaran .

\section{Saran}

Berdasarkan pada kesimpulan-kesimpulan dan implikasi di atas, maka dirumuskan saran-saran sebagai berikut.

6. Pemerintah Pusat, Propinsi dan Kabupaten Gorontalo harus memiliki persepsi yang sama dalam melakukan perubahan-perubahan mendasar dalam sistem manajemen pemerintahan desa untuk dapat meningkatkan Kinerja Kepala Desa dengan cara melakukan pembenahan pada aspek Partisipasi Pelatihan, Responsibility, dan Motivasi Kerja Kepala Desa. 
7. Pada aspek Partisipasi Pelatihan, Pemerintah harus mereformulasikan pemberian peluang mengikuti Pelatihan yang sesuai kebutuhan Kepala Desa dalam memimpin dan menyelenggarakan pemerintahan dan pembangunan di Desa. Hal ini penting, karena latar belakang pendidikan dan strata pendidikan Kepala Desa tidak menjadi determinan faktor dalam proses pemilihan Kepala Desa. Sebagian besar Kepala Desa menduduki jabatan atau dipilih rakyat bukan karena kompetensi yang dimiliki layak memimpin, tetapi lebih banyak didominasi oleh faktor pengaruh dan kharisma figur.

8. Pada aspek Tanggung Jawab Pemerintah Pusat dan Daerah harus memiliki tolok ukur yang jelas dan pasti terhadap kewenangan pemerintah desa disertai dengan pembiayaan yang digunakan untuk menuntaskan beban kerja Kepala Desa. Pembenahan yang terkait dengan Tanggung Jawab Kepala Desa adalah mereview kembali jumlah urusan, kewenangan, dan tugas-tugas yang harus dilaksanakan oleh Kepala Desa sebagai Kepala Pemerintahan Desa.

9. Pada aspek Motivasi Kerja hal-hal yang harus dilakukan perbaikan adalah mereformulasikan sistem penggajian, pemberian tunjangan kesejahteraan Kepala Desa.

10. Pemerintah Kabupaten Gorontalo perlu melakukan perubahan pada pola dan sistem rekrutmen Kepala Desa, karena selama ini tidak mampu mengakomodasi aspek kualitas figur sehingga kelanjutannya pada aspek proses penyelenggaraan pemerintahan dan pembangunan mengalami distorsi. Pemerintah Kabupaten Gorontalo harus lebih bersifat progresif dalam mengotonomkan pemerintahan desa yang ditunjukkan dengan komitmen tinggi dalam hal penyerahan alokasi anggaran penyelenggaraan pemerintahan dan pembangunan desa disertai perangkat-perangkat hukum terkait. Pemerintah Kabupaten Gorontalo perlu mengembangkan sistem penilaian kinerja Kepala Desa yang standar, praksis dan aplikatif.

\section{DAFTAR PUSTAKA}

Armstrong and Murlis. Reward Managemen. United Kingdom: Hay Group, 2008.

Armstrong, Michael, dan Baron, Angela. Performance Management. London: Instituteof Forsonaland development, 2001. 
Armstrong, Michael. A Handbook of Human Resource Management Practice. Philadelpia: Kogan Page, $10^{\text {th }}$ edition, 2006.

Caine, R. Net. Al. Brain/mind learning principles in action. Thous and Oaks: CA, Corwin Press, 2005.

Colquitt, Jason A., Jeffery A. Lepine., and Michel J. Wesson. Organizational Behavior, Improving Performance and Commitment in the Workplace. NewYork: McGraw-HillIrwin, 2009.

Gibson, James J., Jhon Ivancevvick., James H. Donelly. Organization: Behavior, Structure, Proceses. New York: McGraw-Hill, Companies, Inc., 2006.

Ivancevic, A, MBA \& Collin, P. H. Human Resources and Personnel Management. Italy: A \& C Black Publishers Ltd., 2006.

2008. . dkk. Perilaku dan Manajemen Organisasi. Jakarta: Erlangga, jilid 1 dan 2, . Human Resources Management. Canada: McGraw-Hill, Irwin, 2002.

Lynch, Thomas D \& Cruise, Peter L. Handbook of Organization Theory and Management - 2nd ed. Pensylvania: Taylor and Francis 2006.

Mathis. R. L. dan Jackson, J. H. Manajemen Sumber Daya Manusia. Jakarta: Salemba Empat, 2002.

Mulins, Laurie J. Essentials of Organisational Behaviour. Endinburg: Limited, Pearson Education, 2006.

Parasuraman. R, Hancock, P. A. Adaptive control of mental workload. In P. A. Hancock \& P. A. Desmond (Eds.), Stress, Workload, and Fatigue (pp. 305-333). Lawrence Erlbaum: Mahwah, NJ, 2001.

Robbins, Stephen P. Prilaku Organisasi. terjemahan Benyamin Molan, Jakarta: PT. Indeks, 2006.

Robins, Stephen P. \& Coulter, Mary. Management. New Jersey: Pearson International Edition, 2007.

Schermerhorn, John R. Organizational Behaviour. New York: John Wiley \& Sons, 2010.

Ulrich, David. Human Resouces Management. San Fransisco: John Wiley and Sons, 2007. 